\title{
GRICE'S COOPERATIVE PRINCIPLES VIOLATION IN THE COMMUNICATION OF CHILDREN WITH AUTISM
}

\author{
Dian Wahyunianto ${ }^{1}$, Djatmika, ${ }^{2}$ dan Dwi Purnanto ${ }^{3}$ \\ ${ }^{1}$ Pascasarjana, Universitas Sebelas Maret, Jl. Ir.Sutami No. 36 A, Surakarta, 57126 \\ ${ }^{2-3}$ Fakultas Ilmu Budaya, Universitas Sebelas Maret, Jl. Ir.Sutami No. 36 A, Surakarta, 57126 \\ E-mail: 1ianhenshin01@gmail.com; 2djatmika@staff.uns.ac.id; 3dwi.purnanto@yahoo.com
}

\begin{abstract}
The involvement of children with autism in social interaction is mostly at a lower level. It is due to the language obstacles faced by children with autism that become the reason why children with autism tend to violate the cooperative principles in communication. This study aims to demonstrate how children with autism violate Grice's cooperative principles maxims and what causes it. The Grice's cooperative principles maxims are the focus of this observation and 5 children with autism were the subjects of this study. The research was done in SLBN Surakarta which is the school for exceptional children in Surakarta. By utilizing the observational approach, the data were collected using recording and transcribing technique. Leech's heuristic pragmatic analysis method was used to analyze the data. The results showed that $67.65 \%$ of utterances spoken by the children with autism violated 1 maxim, 20.59\% utterances violated 2 maxims and 3 maxims violation was found in $2.94 \%$ utterances. 4 maxims violation was also found indicating that there are $8.82 \%$ utterances of the children with autism failed to fulfill cooperative principles. Language and social development problems are considered responsible for the violations well as their disability to stay focus are considered the cause of maxim of relevance become the most violated maxim in this study.
\end{abstract}

Key words: autism; Grice's cooperative principles; conversational maxim violation

\section{PELANGGARAN PRINSIP KERJA SAMA GRICE DALAM KOMUNIKASI ANAK AUTIS}

\begin{abstract}
ABSTRAK. Keterlibatan anak autisme dalam interaksi sosial sebagian besar berada di tingkat yang rendah. Hal ini disebabkan oleh berbagai kendala kebahasaan yang dihadapi oleh anak autis yang menjadi alasan mengapa anak autis cenderung melanggar prinsip kerja sama dalam komunikasi. Penelitian ini bertujuan untuk menunjukkan bagaimana anak autisme melanggar prinsip-prinsip kerja sama Grice dan apa yang menyebabkannya. Prinsip-prinsip kerja sama Grice menjadi fokus dari penelitian ini dan 5 anak autis menjadi subjek penelitian ini. Penelitian ini dilakukan di SLBN Surakarta. Dengan menggunakan metode simak, data dikumpulkan dengan menggunakan teknik rekam dan catat. Metode analisis pragmatis heuristik Leech digunakan untuk menganalisis data. Hasil penelitian menunjukkan bahwa 67,65\% tuturan oleh anak autis melanggar 1 maksim, 20,59\% tuturan melanggar 2 maksim serta pelanggaran 3 maksim ditemukan pada 2,94\% tuturan. Pelanggaran 4 maksim juga ditemukan dan menunjukkan bahwa ada 8,82\% tuturan anak autis gagal memenuhi prinsip kerja sama. Gangguan perkembangan bahasa dan sosial dianggap bertanggung jawab atas terjadinya pelanggaran. Ketidakmampuan mereka untuk tetap fokus juga dianggap sebagai penyebab maksim relevansi menjadi maksim yang paling banyak dilanggar dalam penelitian ini.
\end{abstract}

Kata kunci: autisme; prinsip kerja sama Grice; pelanggaran maksim

\section{INTRODUCTION}

Autism is a developmental disorder which also affects the language development in the individual with autism. Peeters (2004:15) also mentioned that autism is a developmental disorder, understanding or pervasive disorder and not a mental disorder. Almost all of the autism cases originated from either birth or infancy and affect the developing brain that leaves them unable to form a normal social relationships and develop normal communication (Frith, 2008; Baron-Cohen and Bolton, 1993). As also set out in DSM-IV and previous studies, children with autism are associated with several criteria such as difficulties in social interaction, verbal and non-verbal communication impairments and repetitive actions, all present from early childhood (Baron-Cohen, 2008; Hill \& Frith, 2003; American Psychiatric Association, 2000).

Severe deficits in language are the most noticeable problem found in children with autism (Loveland, 1988;
Paul, et.al., 2008). Several language problems faced by children with autism have been listed by Baron-Cohen and Bolton (1993:47) namely, preverbal communication, nonverbal communication, abnormalities in speech, echolalia, metaphorical language, neologisms, pronoun reversal, and problems with language system itself. Sastry and Aguirre (2012:206) strengthen this view by stating that most of the individual with autism have difficulties in using language effectively, particularly in social interaction. To date, numerous researchers that have studied the language of children with autism mostly only focused on language acquisition problems and speaking ability (Sari, 2013; Dewi, 2014; Ezmar and Ramli, 2014) although, what it really needs to be revealed nowadays is the report on how children with autism involve in the conversation or their pragmatic competence.

The involvement of children with autism in social interaction is somehow unpredictable and mostly at a lower level (Jones \& Schwartz, 2009; Larkin, Hobson, 
Hobson, \& Tolmie, 2017). Nevertheless, the low involvement of children with autism in social conversation can be found out using the maxim violation of cooperative principles (Grice, 1989). As stated by Huang (2007) that the cooperative principles aim to ensure if utterance in the conversation provides adequate information and it is conducted in truthful, relevant, and appropriate manner.

However, Robiah et.al. (2016) and Rahman (2017) found out that children with autism have problems in giving responses to speech acts conducted by the teachers in the classroom context. In his findings, Rahman (2017) stated that children with heavy autism tend to respond the teachers' speech act using non-verbal response, meanwhile, Robiah et.al. (2016) concluded that the more verbal ability children with autism have, the more various responses they made for the directive speech act performed by the teachers. Besides, a study by Whyte and Nelson (2015) also attempted to explain the development of pragmatic and non-literal language in children with autism. Nevertheless, the conversation skill of the children with autism remains unclear since most of the previous studies only revealed the understanding or receptive aspects.

Referring to the inadequacy of the study that focused on the conversational ability, this paper attempts to analyze how children with autism communicate using the Grice's cooperative principles. This paper will utilize Grice's theory that first time introduced in the article "Logic and Conversation" published in 1975 which proposing ideas in obtaining appropriate conversational exchange by paying attention to 4 maxims of cooperative principles. Borrowing the terms previously used by Kant, Grice named his 4 maxims, (1) Quantity, (2) Quality, (3) Relation, and (4) Manner (Grice, 1989).

Due to the language obstacles faced by children with autism as stated in the previous works, it can be hypothesized that children with autism tend to violate the cooperative principles in communication. Hence, this paper specifically focuses on the violation of cooperative principles done by the children with autism. The results of this study aim to demonstrate how children with autism violate each maxim and what causes it.

\section{METHOD}

The design of this study is qualitative research which utilizing the descriptive methods. It is because the objective of subjective research is to depict social phenomena in a natural characteristic manner. It is believed that the qualitative method offers an effective way of picturing what happens in the field. The benefit of the use of the qualitative approach in this study is its flexibility in its implementation. Besides, several previous pieces of research on cooperative principles (Devi \& Qomaruddin, 2017; Lazulfa \& Pamolango, 2017; Zebua, Rukmini \& Saleh, 2017; and Raharja \& Rosyidha, 2019) also utilized qualitative design.

Data in this study are utterances spoken by 5 children with autism. The data were taken in SLBN Surakarta which is a school for exceptional children. In SLBN Surakarta, there are specific classes for children with autism that also come in different levels of education. 5 students who are the subjects of this study are consisting of 2 students from the elementary school level and 3 students from the middle school level. In addition, the subjects were verbal autistic children that have been diagnosed based on DSMIV criteria (American Psychiatric Association, 1994) and internal school assessment in the placement test. The data were taken in March 2018 and taken in the format of the video (audio-visual).

As stated above, the data were in the form of audiovisual or video format. It implies that the data collection was using the SBLC method proposed by Sudaryanto (1993:134). SBLC is Simak Bebas Libat Cakap or Free Conversational Participatory Observation. The technique used is recording and transcribing. Therefore, right after the video was taken, it was then transcribed to convert the audio-visual data into text so that it can be analyzed linguistically.

In analyzing the data, Leech's heuristic pragmatic analysis (1993:63) is used to analyze the utterances spoken by the children with autism that violate cooperative principles. The data are classified based on 4 maxims of cooperative principles by Grice, afterward. Finally, data are presented formally by using a table as well as informally by using words and sentences to simplify the analysis and conclusion drawing process as well as to make it easy to understand.

\section{RESULT AND DISCUSSION}

\section{Cooperative Principles Violation by Children with Autism}

The analysis showed that children with autism tend to violate at least one maxim in their every utterance. The violation of each maxim is based on the sub-maxim explained by Grice (1989:26) that clarified what is considered cooperative utterance and what is not. Based on those ground rules set by Grice, each utterance spoken by the children with autism was then analyzed. Surprisingly, the results demonstrate that not only 1 single maxim is violated in one utterance, but some utterances contained multiple maxims violations. Table 1 presents the data calculation based on the violation form. 
Table 1. Cooperative Principles Maxims Violations

\begin{tabular}{lcc}
\hline \multicolumn{1}{c}{ Violation Form } & Total & Percentage \\
\hline 1 Maxim Violation & 23 & $67.65 \%$ \\
2 Maxims Violation & 7 & $20.59 \%$ \\
3 Maxims Violation & 1 & $2.94 \%$ \\
4 Maxims Violation & 3 & $8.82 \%$ \\
\hline Total & 34 & $100 \%$ \\
\hline
\end{tabular}

\section{Cooperative Principles 1 Maxim Violation by Children with Autism}

As shown in table 1, 1 maxim violation stands on the highest number of frequencies. It implies that in communication, children with autism are likely to make minor violations in their utterances. In table 2, it shows that maxim of relevance becomes the most violated maxim in 1 maxim violation done by children with autism. Maxim of relevance was violated in $52.17 \%$ utterances of 1 maxim violation utterances. In the second place, maxim of quality as a single violation appeared in $26.09 \%$ utterances. The least violated maxims are maxim of quantity in $13.04 \%$ utterances and subsequently, $8.70 \%$ utterances violated maxim of manner.

\section{Table 2. Cooperative Principles 1 Maxim Violations}

\begin{tabular}{lcc}
\hline \multicolumn{1}{c}{ Maxim } & Total & Percentage \\
\hline Maxim of Quantity & 3 & $13.04 \%$ \\
Maxim of Quality & 6 & $26.09 \%$ \\
Maxim of Relevance & 12 & $52.17 \%$ \\
Maxim of Manner & 2 & $8.70 \%$ \\
\hline Total & 23 & $100 \%$ \\
\hline
\end{tabular}

Table 2 has shown that maxim of quantity was violated in $13.04 \%$ utterances of 1 maxim violation by children with autism. Below is the data example of maxim of quantity violation,

(a)

$$
\begin{array}{ll}
\text { - Teacher } & \text { Kalendernya tidak ada, dimana ya? Siapa } \\
& \text { yang mengambil? } \\
& \text { Pelajarannya apa hari senin? } \\
& \text { (The calendar is gone, where is it? Who } \\
& \text { did take the calendar? Well, what are the } \\
& \text { lessons on Monday?) } \\
\text { - Gatematika } & \text { (Mathematic) }
\end{array}
$$

In (a), the dialog happened in the morning before the lesson begin. The teacher was about to write down the date on the board but then found out that the calendar in the classroom was gone. Thus, the teacher was asking where the calendar to the students where there were 3 students in the class. In addition, the teacher also asked about the lesson they had every Monday. Turns out, only one student responded it and he even only answered one question of the 3 questions total. Ultimately, he only answered that one question with an incomplete answer.
It is considered violating maxim of quantity because the teacher was asking 3 questions in a row while, the student only answered 1 question. The teacher expected to get "enough" information from the students including where the calendar is and who took it whereas, the only question being answered was not answered adequately as well. The expected answer would be more than 1 lesson since the teacher was asking about the schedule.

The context explained above shows that the students, the child with autism, could not provide a sufficient quantity of information expected by the teacher. As Grice (1989:26) pointed out, maxim of quantity is consisting of 2 sub-maxims which are 1) make your contribution as informative as is required, and 2) do not make your contribution more informative than is required. The lack of information given by the children with autism is due to their lack of attention to the teacher as their social conversation partner. It is in line with the explanation by Baron-Cohen and Bolton (1993:41) that extracted Kanner's description into a list stated that children with autism are having lack attention to people. The small number of utterances that violated maxim of quantity is in line with the finding of the study done by Lam and Yeung (2012) which reported that autistic children had adequate verbal output. However, such a previous study was done only by measuring the pragmatic ability of the children with autism using the Pragmatic Rating Scale and did not specifically study the cooperative principles among the children with autism. Moreover, what is also important in the conversation is maxim of quality which is described in the paragraph below.

About $26.09 \%$ of utterances spoken by the children with autism in the conversation with the teacher violated the maxim of quality. It can be seen in table 2 . It indicates that children with autism provided information that is believed to be untrue. As stated by Grice (1989:27), what makes the utterance is considered cooperative is when it follows the 2 sub-maxims of maxim of quantity namely, 1) do not say what you believe to be false, and 2) do not say that is you have lack of adequate evidence. The following is the data example of maxim of quality in 1 maxim violation.

(b)

$$
\begin{array}{ll}
\text { - Teacher } & \text { Siapa yang ngasih sehat? } \\
\text { - L } & \text { (Who does give us the health?) } \\
& \text { Saya } \\
& \text { (I do) }
\end{array}
$$

Dialog (b) took place after the teacher took the attendance list and found out that few students were not coming due to health problems. After asking the students to pray for those who were absent to be blessed with health, the teacher asked the rest of the students who gave 
them health and prosperity. Only one student responded to it by saying "I do". Based on this answer, it showed that the student was uncooperative by violating the maxim of quality. What the teacher expected to be the answer was "God" which everyone would agree on it. However, the student was providing information that what he believed to be untrue.

The spontaneous answer that violated the maxim of quality happened due to what is believed to be repetitive behavior and echolalia (Baron-Cohen and Bolton, 1993: 50)of the children with autism. The student responsively said "I do" (or "I am", when in Bahasa Indonesia it can be expressed simply by saying "saya") since that is the template answer for the question " who". This is in line with one of the diagnoses in DSM-IV which is a stereotyped and repetitive use of language or idiosyncratic language that was found in the student (American Psychiatric Association, 1994:75).

As mentioned in the introduction of this paper, Autism Spectrum Disorder, or simply autism, is such a developmental disorder. Baron-Cohen and Bolton (1993: 1) asserted that autism is a condition that leaves the children with autism unable to develop normal communication. Thus, the response showed in (b) is proof that there was a disturbance in children with autism's language development. As Pan and Snow (1999:233) in Dardjowidjojo (2003:266) mentioned that children in the age of $1 ; 8$ only responded around $33 \%$ to what their parents asked. However, it still can be found in an individual who is not well-developed in their language aspect, in this case, children with autism.

In 1 maxim violation of children with autism, table 2 shows that maxim of relevance has the highest score among other 1 maxim violations. 52.17\% utterances of children with autism were found violating maxim of relevance. It shows similar results with the case study on 6 years-old kid done by Shinta (2010) indicating that maxim of relevance appeared to be the highest in the utterance. For the better understanding of how the children with autism violate maxim of relevance, below is the data example of maxim of relevance violation in the utterance of children with autism,

(c)

$$
\begin{array}{ll}
\text { - Teacher } & \text { Biar hafal. Biar mengerti. } \\
\text { - G } & \text { (To remember. To understand) } \\
& \text { Lama ngga ada upacara ya, bu? } \\
& \text { (Long time without ceremony, } \\
& \text { right ma'am?) }
\end{array}
$$

The context of the dialog (c) is the conversation between the student and the teacher in the class. It occurred when the teacher told the students that the lesson they would have that day was a repetition of what they had in the previous week. The teacher assured the student that it was important to repeat what they had learned to make them remember better and to make them understand better. Nonetheless, one student was offering one question about the absence of morning ceremony for several weeks that they used to have every Monday.

The utterance is considered violating maxim of relevance due to the irrelevant response made by the student. As stated by Grice (1989:27) that the sub-maxim under the maxim of relevance is just 1 which is "be relevant". The irrelevant response done by the student was the inability of the student to stay focus on one topic being talked and give an appropriate comment on it. It is relevant to what stated by Jones and Schwartz (2009) that children with autism tend to engage in fewer comments in the particular interaction. Commenting means that the participant of the conversation response to what another participant in the conversation.

However, there another possibility of what inside this student's mind while responding that way. It is the student who did that on purpose to refuse to study since it happened before the lesson began. Thus, this case can be categorized as opting-out the maxim of relevance. Opting out maxim is when the speaker is unwilling to cooperate in the way the maxim requires (Grice, 1989:30). Such uncooperative behavior of the children with autism was also found highly in several studies on communication and uncooperative behavior in dental or oral check-up setting (Marshal et.al., 2007; and Stein et.al., 2014).

As shown in table 2, the 1 maxim violation of maxim of manner appeared to be the least among others. It only occurred in $8.70 \%$ utterances spoken by the children with autism. In contrast, there are many language problems that children with autism face (Baron-Cohen and Bolton, 1993:47) which is likely to lead them in violating maxim of manner as the sub-maxim of it consisting of more categories than other maxim. The sub-maxims under the maxim of manner that are proposed by Grice (1993:27) are 1) avoid obscurity of expression, 2) avoid ambiguity, 3) be brief, and 4) be orderly. The following is the data example of 1 maxim violation of maxim of manner,

(d)

- Teacher Iya.R? Kita mau belajar apa? (Alright, R? What are we going to learn (today)?)

- R Ma...te...ma...ti...ka

(Math...e...ma...tic)

The conversation in $(d)$ occurred when the teacher asked one particular student to bring his focus back. The question asked by the teacher was just a simple question asking what they would learn. The expected answer would be "matematika" and, luckily, the student successfully 
gave the correct answer. However, the way the student answer the question was the main problem. Instead of saying it with a normal manner, the student spelled each syllable of the word. It is violating the sub-maxim which is "be brief" in the maxim of manner.

This result indicates that children with autism violate maxim of manner mostly due to their speech ability condition. In this case, the student was having difficulties in saying something quickly and smoothly for particular words that are considered "tongue twister" since the word "matematika" consisting bilabial and dental, and glottal consonants. Therefore, he needed to pronounce it carefully by spelling each syllable. Besides, it is a common case that individual with autism speaks with unusual syllable spelling stress (Grossman, et.al, 2010; Paul, et.al., 2008; Shriberg, et.al., 2001; and Shriberg, et.al., 2011).

The following section moves on to describe 2 maxims violation in the communication of children with autism.

\section{Cooperative Principles 2 Maxims Violation by Children with Autism}

Regarding table 2, it has exposed that 2 maxims violation became the second-highest phenomenon that occurred in the conversational cooperative principles of children with autism. It is reported that $20.59 \%$ of the utterances of the children with autism had violated 2 maxims combined. However, there are only 4 combinations emerged in this case. These combinations are 1) maxim of quantity-maxim of relevance, 2) maxim of quantity-maxim of manner, 3) maxim of quality-maxim of relevance, and 4) maxim of quality-maxim of manner. Table 3 shows the frequency of 2 maxims combination violation appeared in the utterances produced by the children with autism,

\section{Table 3. Cooperative Principles 2 Maxims Violations}

\begin{tabular}{lcc}
\hline \multicolumn{1}{c}{ Maxim Combination } & Total & Percentage \\
\hline Quantity-Relevance & 1 & $14.29 \%$ \\
Quantity-Manner & 2 & $28.57 \%$ \\
Quality-Relevance & 2 & $28.57 \%$ \\
Quality-Manner & 2 & $28.57 \%$ \\
\hline Total & 7 & $100 \%$ \\
\hline
\end{tabular}

In table 3, it can be seen that there is a unique phenomenon that shows no 2 maxims combination dominate in this research finding. 3 maxim combinations have the same number of occurrences in the conversational data. The combination of quantity-manner, qualityrelevance, and quality-manner appeared in $28.57 \%$ utterances of the children with autism. However, only the combination of maxim of quantity and maxim of relevance that was appeared to be the lowest number. Only $14.29 \%$ or 1 utterance violated maxim of quantity and relevance. The only data that violated maxim of quantity and maxim of relevance combined appeared in this research is shown in the dialog (e) below,

(e)

$\begin{array}{ll}\text { - Teacher } & \text {... Belajar dulu yang bagus, nanti } \\ \text { dapat piala ya. Kemarin F habis } \\ \text { lomba comic strip di Semarang. } \\ \text { Tangannya dilipat ya. Belum } \\ \text { mendapatkan juara. Harus lebih } \\ \text { rajin lagi. } \\ \text { (... Study well first to get a trophy. } \\ \text { Last time you joined comic strip } \\ \text { competition in Semarang. Fold } \\ \text { your arms. You haven't won that } \\ \text { time. Need to work harder.) } \\ \text { Yeee... lagi. } \\ \text { (yeay.. again). }\end{array}$

This dialog took place when one of the students was out of focus and started doing stereotyped or repetitive behavior which is scribbling in the book. To bring the student's focus back, the teacher talked to the student directly and asked him to start studying. Several motivations were given to the students for instance, having a trophy when the student is studying well. The teacher also brought back the student's memory about the last comic strip competition that he joined which ended up failing to win. Seeing the student kept scribbling again, the teacher reminded him to fold his arm to stop him from scribbling. Surprisingly, the response of the student was quite interesting. Instead of saying yes indicating that he agreed on the teacher's speech, he responded with interjection "yeay". Following the interjection, the student said "again" out of nowhere without a clear indication which part of the teacher's utterance he responded.

The explanation about the context above proves that the utterances spoken by the student were violating the maxim of quantity and maxim of relevance. As stated by Grice (1989:26) that in conforming maxim of quantity the information given must not less than what is required. However, the "lagi" or "again" uttered by the student was not giving adequate information needed by the teacher as a listener. In addition, it is also unclear and irrelevant in which information the student was trying to respond with such utterance. It seems that the student was imitating the teacher that also said "...lagi" in her utterances. This imitation is unsolicited and can be considered as echolalia (Baron-Cohen and Bolton, 1993: 50).

The other categories shown in table 3 are the combination of maxim of quantity-maxim of manner, maxim of quality-maxim of relevance, as well as maxim of quantity-maxim of manner that shows exactly in identical percentage which is $28.57 \%$. Each category will 
be explained below and it will be started with the category of 2 maxims violation combination between maxim of quantity and maxim of manner that is presented in dialog (f)

- Teacher

$-G$
Ulangi. Sekarang G. Lambangnya seperti ini. Berapa ini?

(Repeat. Now is G's turn. Here's the number. What number is it?)

Seratu...

(hundr...).

Dialog $(f)$ happened in the middle of the lesson when the teacher was asking the students one by one to read the number written on the board. When the teacher asked one particular student, the incomplete answer was all she got. A certain student said "seratu..." which is an unfinished word of "seratus" that means "hundred". This is completely considered violating the maxim of quantity as well as maxim of manner due to the way the student uttering his answer.

Maxim of quantity was violated in this utterance proven by the unfinished word uttered by the student. As stated by Grice (1989:26) that to fulfill maxim of quantity, the speaker must contribute as informative as it is required. Unfortunately, the student was failing in fulfilling the maxim of quantity due to the absent of /s/ sound at the end of the word that indicates a phonological error in his speech. It is in line with the findings of previous research that showed the individual with autism faced some error in speech sound production (Shriberg, et.al., 2001). This error or inability of the student to pronounce the word correctly is undoubtedly violating the maxim of manner which requires the speaker to avoid obscurity in their contribution (Grice, 1989:27).

Besides violating maxim of quantity in combination with maxim of relevance and maxim of manner that has been explained in the previous paragraphs, the utterances produced by the children with autism in this study also violated 2 maxims combined between maxim of quality and maxim of relevance. The following dialog is showing how those maxims were violated simultaneously.

(g)

$\begin{array}{ll}\text { - Teacher } & \text { Batik. Kalo Jumat bajunya? } \\ & \text { (Batik. On Friday, what is your } \\ & \text { uniform?) } \\ \text { - L } & \begin{array}{l}\text { Orange jus } \\ \text { (Orange Juice). }\end{array}\end{array}$

What happened in the dialog (g) was the teacher asking on what is the uniform the students wear every Friday. Such a question came up in line with the topic of that day's lesson which studying name of clothes. In response to the question asked by the teacher, one particular student shout spontaneously by saying "orange juice" as his best answer to that uniform question. Based on the context and the analysis, thus, this data is considered violating maxim of quality and maxim of relevance simultaneously.

The answer "orange juice" as of Friday's uniform undeniably violating the maxim of quality. As a matter of fact, the national school uniform in Indonesia on Friday is Scout Uniform or well-known as Pramuka in Indonesia. This fact supports that the maxim of quality violation made by the student was based on the color of the uniform that the student mistook it as orange. It is in line with what Grice (1989:26) had proposed in the sub-maxim of maxim of quality that the speaker is expected to not say something which they lack adequate evidence. It, later, followed by the word "juice" failed to fulfill the utterance's relevance. Such a phenomenon was also reported on a previous study (Rubin and Lennon, 2004) that stated that children with autism faced difficulties in maintaining a conversation by giving suitable comments for the topic given.

The last 2 maxims combination that appeared to be violated by the children with autism is the combination of the maxim of quality and the maxim of manner. The conversation in $(\boldsymbol{h})$ below is the data found in this study that is used as an example to give a comprehensive explanation about the context and why it is considered violating the cooperative principles.

(h)

$$
\begin{array}{ll}
\text { - Teacher } & \text { :Lihat. Angka berapa ini? } \\
& \text { (Look. What number is this?) } \\
\text { - F } & \text { Satu... Dua...Seratus... } \\
& \text { (One... Two... A Hundred...). }
\end{array}
$$

What is shown in (h) happened when the teacher once again asked the students to mention what number the teacher pointed on the board. This was aiming at improving students' ability to read number and to improve their speaking ability. In asking that question, the teacher was pointing the students one by one. The appointed student, unfortunately, was unable to answer the question correctly. The way he answered it was also confusing by making pauses in each word.

The student's answer, regarding Grice's point of view on communication exchange (1989:26), is considered violating maxim of quality. It is due to what the student expressed through his utterance did not reflect reality. The number written on the board was " 105 ", but the student answering it with "one...two...a hundred". The first word appeared could be tolerated since there was "one" in " 105 ", yet he made mistake by proceeding it with the word "two" where it was nowhere to find. However, he revised his answer by saying "a hundred" although that was not the precise answer either. This case occurred since children with autism have difficulties in staying focus and paying attention. As reported in the pilot study by Mattard- 
Labrecque, et.al. (2013), children with autism tend to have poor sensory processing. This is including poor visual sensory processing causing the student unable to pay attention to the board.

Another maxim being violated in that utterance spoken by the children with autism is maxim of manner. This violation happened as the way the student failed to fulfill the sub-maxim of maxim of manner which is "be brief' (Grice, 1989:27). The student's contribution to the dialog was indeed consisting of pauses that take longer duration in such a short answer. This is another proof that children with autism have problems related to language use (Baron-Cohen and Bolton, 1993:47).

Another finding of this study is the violation of multiple maxims in one utterance, namely 3 and 4 maxims violations. The following section presents the multiple maxim violations in the communication of children with autism.

\section{Cooperative Principles Multiple Maxims Violation by Children with Autism}

Moving on to the multiple maxims violation, it is reported that 3 maxims violations only found in this study in 1 utterance or $2.94 \%$ of total data as presented in table 1. It also represents that 3 maxims violation only have 1 combination of Grice's conversational maxim to be violated, maxim of quantity, maxim of quality, and maxim of manner. Dialog (i) below is presenting the data to give a clearer picture of how these maxims violated.

(i)

$$
\begin{array}{ll}
\text { - Teacher } & \text { : Seratus lima. } \\
& \text { (a hundred and five) } \\
\text { - F } & \text { Se... ratus lima. Seratus... dua SMAN }
\end{array}
$$

(A... Hundred and five. A Hundred... Two S M A N (high school)).

The conversation between the teacher and the student in dialog (i) happened when the teacher was asking the student to follow her word. The utterance of the teacher containing command as it was expressed using a declarative sentence. Therefore, what was expected from the student is imitating what the teacher said. Successfully, the student was able to imitate it even though, subsequently, it was followed by additional yet unimportant information that did not exist on the board. When expressing the phrase "seratus lima" (a hundred five), the student used a pause between the first syllable making it longer.

The student's utterance failed at fulfilling 3 maxims since it has too much information provided which was not based on the fact written on the board and contained long pause that affects the obscurity of his utterance. The information given ended up being wasted since it was not needed by the teacher. Grice (1989:26) already mentioned that in order to fulfill cooperativeness in conversation, the speaker must not contribute more than is required. It was going to be cooperative if the student stopped speaking after answering with "seratus lima" because that is the quantified required answer.

The existence of the additional information given by the student, unfortunately, makes it violating the maxim of quality as well as maxim of manner. The following phrase "seratus... dua SMA N" was an abrupt contribution which was not anticipated by the teacher. Such information given by the student was completely unavailable on the board as what the student expected to do was reading what was written on the board by following the instruction from the teacher. Thus, it is considered violating the sub-maxim of maxim of quality proposed by Grice (1989:27) that is avoiding saying something which the speaker lack of sufficient evidence. Besides, the way the student answered it by giving pauses after the word "seratus" was violating criteria also provided by Grice (1989:27) stated that the utterance or contribution must be brief to fulfill the maxim of manner.

Multiple maxims violations appeared in this study is not only 3 maxims combination violation, but all maxims violated in one utterance also appeared in the finding. In another word, this kind of violation is extremely violating the cooperative principles as a whole making it completely uncooperative. Yet, the number of data found in this study is not high, only $8.82 \%$ or 3 utterances found to be violating all four conversational maxims as can be seen in table 1. For the better understanding of how the children with autism violated all conversational maxims, the dialog (j) below is the data example,

(j)

- Teacher Keluarkan buku matematika dulu, yoo. $R$ ambil buku matematika sama alat menulis. F, ambil buku matematika dan alat tulis

(Take out your mathematic book. $\mathrm{R}$, take your mathematic book and your stationery out. F, take out your mathematic book and stationary)

- F Dududududududu

It can be seen from the dialog (j) provided above, the teacher was asking the students to take out their book and their stationary. It is inferable that this dialog happened before the lesson began on that day. With such simple command from the teacher, it was expected that the student simply took out their book and stationary with or without saying "yes". However, F, was, suddenly, saying some meaningless word repeatedly without responding to the teacher's command to take out his book and stationary.

Sussman and Sklar's (1969) study on social awareness attempted to prove that children with autism 
having ability complying commands given by the workers. It was, surprisingly, showing that persuasive commands tended to be obeyed by the children with autism rather than harsh commands. However, the opposite happened in this study when the student, the child with autism, failed at fulfilling the tasks given by the teacher. This failure was tragically followed by the meaningless speech spoken by the student.

In (j), it can be seen that the teacher was giving persuasive commands to the students, while what the student did was responding with an unclear speech by saying “dududududu”. Indeed, Baron-Cohen and Bolton (1993:47) mentioned that children with autism face many language challenges including speech abnormalities and echolalia. With such a response, it was automatically violating all conversational maxims since there was nothing can be inferred from that utterance. The utterance was completely unable to fulfill adequate information needed, has nothing to do with the reality, was irrelevant, and was totally obscure.

Multiple maxims violation is summarized in table 4 below,

Table 4. Cooperative Principles Multiple Maxims Violations

\begin{tabular}{lcc}
\hline \multicolumn{1}{c}{ Multiple Maxim Category } & Total & Percentage \\
\hline $\begin{array}{l}\text { 3 Maxims } \\
\text { (Quantity-Quality-Manner) }\end{array}$ & 1 & $25 \%$ \\
$\begin{array}{l}\text { 4 Maxims } \\
\text { (Quantity-Quality-Relevance- }\end{array}$ & 3 & $75 \%$ \\
Manner) & 4 & $100 \%$ \\
\hline Total & 4 & \\
\hline
\end{tabular}

\section{Frequency of Cooperative Principles Maxims Violation in Communication by Children with Autism}

In the previous sections, it is already clear that there are several violations identified by how many maxims violated in one utterance. In this section, it focuses on the frequency of the conversational maxims by Grice (1989) that appeared the most, or in other words, violated the most in this study regardless it is 1 maxim violation or combined with other maxims. The calculation of the data is simplified in figure 1 below,

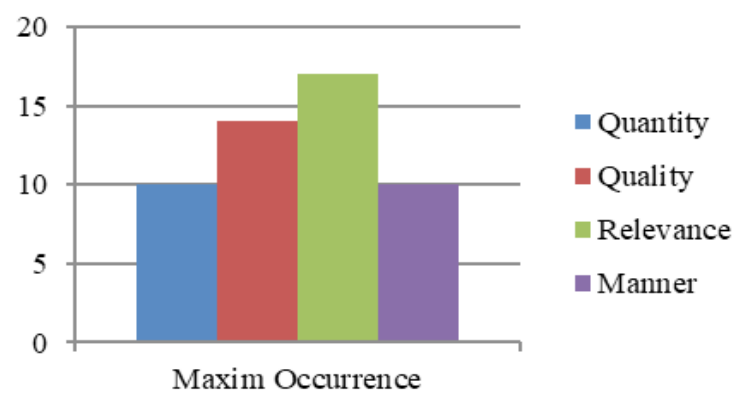

Figure 1. Cooperative Principles Maxim Violation Occurrence Frequency
The charts shown in figure 1 show the frequency of conversational maxims violations that occurred in this study. It can be seen that the maxim of relevance is the highest among other maxims. The maxim of relevance was violated for more than 15 utterances. This tendency is in line with the study done by Shinta (2010) proven that a six-year-old kid tended to violate maxim of manner. The result of her study is comparable with this study since the children with autism are having developmental disorders especially in the pragmatic development they are at the lower level even than normal 2-years olds (Peeters, 2004:15; Loveland, 1988) and considered as late-bloomer. Another reason why maxim of relevance is the most dominant maxim appeared to be violated by the children with autism is because children with autism have difficulties in giving suitable comments in social interaction as well as command compliance with appropriate respond (Jones and Schwartz, 2009; Rubin and Lennon, 2004; Sussman and Sklar, 1969).

Following the maxim of relevance, maxim of quality was found to be the second most violated maxim in the observation done by the researcher. The lack of awareness, poor attention sensory processing, as well as the existence of repetitive behavior (Mattard-Labrecque, et.al., 2013; Baron-Cohen and Bolton, 1993:50) are believed to be responsible of maxim of quality violation. Thus, with such a condition, it is inarguably possible for children with autism to keep violating the maxim of quality.

Maxim of quantity and maxim of manner, as stated in figure 1, were shown to be the same frequency. This phenomenon has proved that even when the children keep violating maxim of relevance, they still are able to provide adequate information needed in the conversation exchange (Lam and Yeung, 2012). However, the speech ability of children with autism tends to have numerous errors due to their language structural problems (Shriberg, et.al., 2001; Baron-Cohen and Bolton, 1993:47; Noterdaeme, et.al, 2010).

\section{CONCLUSION}

As hypothesized at the beginning of this paper, the children with autism tend to violate cooperative principles conversational maxim. It was proven by the findings showing that at least one maxim was violated in their communication. Language and social development are considered responsible for the violation of conversational maxim in their utterances. Their disability to stay focus on something is also the cause of the most violated maxim; maxim of relevance. However, the phenomenon that happened at most is the violation of 1 maxim in a single utterance. Thus, it is recommended for the parents and the teachers of the children with autism to give more stimuli 
by giving persuasive commands and keeping them to stay focus as well as pay more attention. What is needed to be done in the future are observing how the children with autism utilize the Grice's cooperative principles in another environment such as at home or their communication between autistic individual fellow as well as the use of speech acts to convey what is inside their mind. It also needs to do another research with adult individual with autism to see whether there are different results.

\section{ACKNOWLEDGEMENT}

The greatest gratitude is given to the teachers and headmaster of SLBN Surakarta who allowed the researchers to observe the students; the children with autism; in the school environment.

\section{REFERENCES}

American Psychiatric Association. (2000). Diagnostic and Statistical Manual of Mental Disorders (DSM-IV) ( $4^{\text {th }}$ ed.). Washington, DC: American Psychiatric Press.

Baron-Cohen, S \& Bolton, P. (1993). Autism: The Facts. New York: Oxford University Press.

Baron-Cohen, S. (2008). The Facts: Autism and Asperger Syndorme (1st ed.). New York: Oxford University Press.

Dardjowidjojo, S. (2003). Psikolinguistik: Pengantar Pemahaman Bahasa Manusia. Jakarta: Yayasan Pustaka Obor Indonesia. [Indonesian]

Devi, L.N. \& Qomaruddin, M. (2017). Prinsip Kerja Sama dalam Bahasa Transaksi Jual Beli Online di Tokopedia.com. Haluan Sastra Budaya, 1, (1), 8696. Doi: https://doi.org/10.20961/hsb.v1i1.5204/ [Indonesian]

Dewi, D.M.C. (2014). Identifikasi Kemampuan Berbahasa Anak Autis di Sekolah Inklusif SD Negeri Giwangan, Yogyakarta. Universitas Negeri Yogyakarta : Unpublished Thesis [Indonesian]

Ezmar dan Ramli. 2014. Bahasa Anak Autis pada SLB Cinta Mandiri Lhoksumawe. Jurnal Metamorfosa, 2, (2), 1-18. [Indonesian]

Frith, U. (2008). Autism : Very Short Introduction. New York: Oxford University Press

Grice, H.P. (1989). Studies in the Way of Words. Cambridge, M A: Harvard University Press.

Grossman, R.B., Bemis, R.H., Skwerer, D.P. \& Flushberg, H.T. (2010). Lexical and Affective Prosody in
Children with High-Functioning Autism. Journal of Speech, Language, and Hearing Research, 53, 778-793. Doi: 10.1044/1092-4388(2009/08-0127)

Hill, E.L. \& Frith, U. (2003). Understanding autism: Insights from mind and brain. Philosophical Transactions of the Royal Society B: Biological Sciences, 358, (1430), 281-289. https://doi. org/10.1098/rstb.2002.1209

Huang, Y. (2007). Pragmatics. New York: Oxford University Press.

Jones, C.D. \& Schwartz, I.S. (2009). When Asking Questions is Not Enough: An Observational Studyof Social Communication Differences in High Functioning Children with Autism. Journal of Autism and Developmental Disorders, 39, 432443. Doi: https://10.1007/s10803-008-0642-y/

Lam, G.L. \& Yeung, S.S.S. (2012). Towards a convergent account of pragmatic language deficits in children with high-functioning autism: Depicting the phenotype using the Pragmatic Rating Scale. Research in Autism Spectrum Disorders, 6, 792797. Doi: https://10.1016/j.rasd.2011.08.004/

Larkin, F., Hobson, J.A., Hobson, R.P., \& Tolmie, A. (2017). Collaborative competence in dialogue: Pragmatic language impairment as a window onto the psychopathology of autism. Research in Autism Spectrum Disorders, 43-44 (September), 27-39. https://doi.org/10.1016/j.rasd.2017.09.004

Lazulfa, F.I. \& Pamolango, V.A. (2017). A Study of Cooperative Principles in Conversation of Tenants at Kampoeng Inggris Pare, Kediri. Parafrase, 17, (1), 81-87. doi: https://doi.org/10.30996/parafrase. v17i1.1363/ [Indonesian]

Leech, G. (1993). Prinsip-prinsip Pragmatik. Jakarta: Universitas Indonesia Press

Loveland, K.A., Landry, S.H., Hughes, S.O., Hall, S.K. \& McEvoy, R.E. (1988). Speech Acts and the Pragmatic Deficits of Autism. Journal of Speech and Hearing Research, 31, (4), 593-604. doi: 10.1044/jshr.3104.593/

Marshal, J., Sheller, B., Williams, B.J., Mancl, L. \& Cowan, C. (2007) Cooperation Predictors for Dental Patients with Autism. Pediatric Dentstry, 9, (5), 369-376. Retrieved from: https://www.ncbi. nlm.nih.gov/pubmed/18027770/

Mattard-Labrecque, C., Amor, L.B. \& Couture, M.M. (2013) Children with Autism and Attention Difficulties: A Pilot Study of the Association between Sensory, Motor, and Adaptive Behaviors. 
Journal of the Canadian Academy of Child and Adolescent Psychiatry, 22, (2), 139-146. Retrieved from: https://www.ncbi.nlm.nih.gov/pmc/articles/ PMC3647630/

Noterdaeme, M., Wriedt, E., \& Höhne, C. (2010). Asperger's Syndrome and High-Functioning Autism: Language, Motor and Cognitive Profiles. European Child and Adolescent Psychiatry, 19, 475-481. doi: https://10.1007/s00787-009-0057-0/

Paul, R.., Bianchi, N., Augustyn, A., Klin, A. \& Volkmar, F.R. (2008). Production of Syllable Stress in Speakers with Autism Spectrum Disorders. Research in Autism Spectrum Disorders, 2008, (2), 110-124. doi: 10.1016/j.rasd.2007.04.001

Peeters, T. (2012). Panduan Autisme Terlengkap. Jakarta: Dian Rakyat Press. [Indonesian]

Raharja, A.U.S \& Rosyidha, A. (2019). Maxim of Cooperative Principle Violation by Dodit Mulyanto in Stand-up Comedy Indonesia Season 4. Journal of Pragmatic Research, 1, (1), 43-61. doi: $\quad$ http://dx.doi.org/10.1836/jopr.v1i1.62-77/ [Indonesian]

Robiah, S., Ibrahim, A.S. \& Rofi'udin, A. (2016). Respon Tutur Siswa Autis terhadap Tutur Direktif Guru dalam Interaksi Pembelajaran di Kelas. Bahasa dan Seni, 44, (2), 111-124. doi: http:// dx.doi.org/10.17977/um015v44i22016p111/ [Indonesian]

Rubin, E. \& Lennon, L. (2004). Challenges in Social Communication in Asperger Syndrome and HigFunctioning Autism. Topic in Language Disorders, 24, (4), 271-285. doi: 10.1097/00011363200410000-00005

Sari, H.C. (2013). Pengaruh Dongeng terhadap Kemampuan BicaraAnak Autis Disertai Gangguan Bahasa di SDLB Shanti Kosala, Nganjuk. Jurnal Pendidikan Khusus, 1 (1). [Indonesian]

Sastry, A. \& Aguirre, B. (2014). Parenting Anak dengan Autisme: Solusi, Strategi, dan Saran Praktis untuk Membantu Keluarga Anda. Yogyakarta: Pustaka Pelajar. [Indonesian]
Shinta, Q. (2010). Pemerolehan Pragmatik dalam Bahasa Anak Studi Kasus Prinsip Kerja Sama - Maksim Grice pada Anak Usia Enam (6) Tahun. Dinamika Bahasa Dan Budaya, 4(2), 66-83. Retrieved from https://www.unisbank.ac.id/ojs/index.php/fbib1/ article/view/423/ [Indonesian]

Shriberg, L.D., Paul, R., McSweeny, J.L., Klin, A., Volkmar, F. R. \& Cohen, D.J. (2001). Speech and Prosody Characteristics of Adolescents and Adults with High Functioning Autism and Asperger Syndrome. Journal of Speech, Language, and Hearing Research, 44, 1097-1115. doi: https://1092-4388/01/4405-1097/

Shriberg, L.D., Paul, R., Black, L.M., \& van Santen, J.P. (2011). The Hypothesis of Apraxia of Speech in Children with Autism Spectrum Disorder. Journal of Autism and Developmental Disorders, 41, 405426. doi: https://10.1007/s10803-010-1117-5/

Stein, L.I., Lane, C.J., Williams, M.E., Dawson, M.E., Polido, J.C. \& Cermak, S.A. (2014). Physiological and Behavioral Stress and Anxiety in Children with Autism Spectrum Disorders during Routine Oral Care. BioMed Research International, 2014, 1-10. Doi: http://dx.doi.org/10.1155/2014/694876/

Sudaryanto. (1993). Metoda dan Aneka Teknik Analisis Bahasa. Yogyakarta: Duta Wacana University Press. [Indonesian]

Sussman, S. \& Sklar, J.L. (1969). The Social Awareness of Autistic Children. American Journal of Orthopsychiatry, 39 (5), 798-806. doi: https://doi. org/10.1111/j.1939-0025.1969.tb00662.x

Whyte, E.M. \& Nelson, K.E. (2015). Trajectories of Pragmatic and Nonliteral Language Development in Children with Autism Spectrum Disorders. Journal of Communication Disorders, 54.2-14.doi: http://dx.doi.org/10.1016/j.jcomdis.2015.01.001/

Zebua, E., Rukmini, D. \& Saleh, M. (2017). The Violation and Flouting of Cooperative Principles in the Ellen Degeneres Talk Show. Language Circle: Journal of Language and Literature, 12, (1), 103-113. doi: https://doi.org/10.15294/lc.v12i1.11474 